\title{
Forum
}

\section{Tenure Talk}

The PS symposium Tenure Trouble (March 1997) dealt with important issues, especially the trend of applying the business model to academia. Thinking of the university as a business, I believe, is the root of most of the problems related to tenure and the others matters discussed.

The business model was clearly evident in the 1970s, although it began to be applied much earlier. It occurred mainly among the secondand lower-ranked institutions although the major-, high-prestige universities were not immune, particularly the state-financed ones. "Student production" accounting and a corporate management style are illustrative of the trend. The demise of the old German university model of the department chair is another: the ideal was that a chair was not much more than a convener. Today, most chairs are full-time, less likely to be dedicated scholars, and part of university management.

The pressures for the business model are understandable since boards of regents or trustees are mainly from business and often political appointees. One response by faculty has been breast beating ("isn't it awful that regents/trustees don't understand what we do and what is involved in the 'search for truth" "); another is the claim of "shared governance" which is akin to the company union; and a third is the head-in-the-sand approach ("as a dedicated scholar I'll just do my work and won't get involved in controversies").

Faculty unionization has not fared well. Unfortunately, many faculty feel a possible loss of status or believe they are part of a calling which shouldn't be sullied by collective action. Questions regarding tenure, teaching loads, fair evaluation, and opportunity for new Ph.D.s, particularly for minorities and women, will be increasingly determined by business-oriented university manage- ment. Eventually, faculty members may realize they have only their labor to sell, and that a meaningful response to the business model is unionization.

Irving Krauss

Northern Illinois University

\section{Taking Exception}

Gregory Bruce Smith's solid essay "Leo Strauss and the Straussians: An Anti-Democratic Cult?" (June 1997) attempts to challenge the current image of the late Leo Strauss as anti-democratic. The simplistic images and "intemperate" accusations surrounding Strauss in the popular press and in recent scholarly works, according to Smith, do not do justice to the complexity of his thought. While Smith does a fine job presenting Strauss's thought, he fails in what seems to be his initial project-defending Strauss against the accusation that he was anti-democratic. On the contrary, notwithstanding his constant pronouncements that Strauss was a supporter and defender of Liberal Democracy, Smith in fact reveals why Strauss's political thought is properly seen as "anti-democratic."

Smith juxtaposes Strauss's thought with the liberal democratic ideological outlook which views history as progress towards a universal cosmopolitan society. Smith alleges that proponents of this view, among Strauss's contemporaries, were willing to overlook "Stalinist oppression" because they were so "mesmerized" by the idea of a progressive history and the promise of increasing equality (Smith 1997, 186). From the standpoint of those who see history as necessarily progressive, Smith asserts, Strauss might appear to be an anti-modern conservative or even reactionary.

Smith's characterization of the outlook of progressivist cosmopolitanism, in contrast to which Strauss's thought is presented, discloses the anti-liberal democratic core of Straussian thought. Strauss believed that modernity-understood in terms of the scientific conquest of nature and the quest for equality-signified a turn down the road to this cosmopolitan society. As Smith indicates, Strauss regarded such a universal cosmopolitan society as a "universal tyranny in which all man's higher possibilities and aspirations would be strangled" (Smith 1997, 186).

It is this simplistic, immoderate and ultimately paranoid characterization of the consequences of modernity which betrays Strauss's profound hositility to modern liberal democracy. Despite Smith's halfhearted disclaimer that Strauss did not really think this end of history scenario was possible, Strauss certainly seemed to take his ominous vision of an "end of history" very seriously. Smith, himself, observes that the moral and scientific understanding forged at the onset of the modern age "led in an inevitable direction, toward 20 th century relativism and nihilism and, as a result, political tyranny" in Strauss's view. Strauss's apprehension of this new universal tyranny is especially clear in his famous exchange with Kojeve, to which Smith calls attention.

Kojeve, Strauss affirms, is right to predict the advent of the universal and homogeneous state, but this state, he insists with a note of desperation, will signify the "end of philosophy on earth" (Strauss 1963, 226). Only perhaps a monumental "nihilistic negation" of the impending universal state will save us from this fate, in Strauss's view (Strauss 1963, 224).

In a footnote, Smith disparagingly refers to Stephen Holmes's depiction of Strauss as an anti-liberal in The Anatomy of Antiliberalism. Holmes, in Smith's view, uses the questionable tactic of making Strauss guilty by association by comparing him with Joseph de Maistre and Carl Schmitt. He misses, I think, the real 
value of Holmes's overall critique of anti-liberalism which is to disencumber liberalism of the myths, misconceptions and dogmas fostered by the anti-liberal outlook. The idea that modern liberal democrats are mesmerized by the ideal of the equalitarian universal state and are unable or unwilling to consider the costs of this state is one such a myth. The idea that modernity must decay into universal tyranny and dull passivity is another. These misconceived characterizations of modern liberal democracy were constant underlying themes of Strauss's thought.

\section{References}

Smith, Gregory Bruce. 1977. "Leo Strauss and the Straussians: An Anti-Democratic Cult?" PS, 30(2): 180-89.

Strauss, Leo. 1963. On Tyranny. Ithaca: Cornell University Press.

Regina F. Titunik

University of Hawaii-Hilo

\section{THE DIRECTORO OF WOMEN OF COLOR IN POLITTCAL SCIENCE}

A joint project between the Women's Caucus for Political Science and APSA's Committee on the Status of Women in the Profession, the directory was designed to assist graduate students in their search for mentors. Nearly 300 APSA members are included in the directory, with their addresses, telephone, e-mail and fax numbers. Each listing includes the member's current position, institution and date of highest academic degree, as well as fields and subfields of specialization and membership in Organized Sections.

\section{口 ORDER FORM}

Enclosed is payment for copies of the

Directory of Women of Color in Political Science at the rate of $\$ 6.00$ for each copy.

\section{$\square$ CHECK ATTACHED DVISAMASTERCARD}

No.

Exp. Date

Signature

\section{ALL ORDERS MUST BE PREPAID}

Name

Address

City/State/zip

Pfine

MAIL TO:

Publications/APSA

1527 New Hampsfire Avenue, NW Wasfington, DC 20036-1290

or fax your order to:

(202) 483-2657 